\title{
Proteomics Profiling of Crassostrea Iredalei Exposed to Toxic Alexandrium Tamiyavanichi and Non-Toxic Alexandrium Leei
}

\author{
Nurul Ashima Hamdan, Siti Noor Hasmiza Mamat, Muhamad Shafiq Abu Hassan, Noormawaty \\ Mohammad Nor and Noraslinda Muhamad Bunnori \\ Kulliyyah of Science, International Islamic University Malaysia, Pahang, Malaysia
}

\begin{abstract}
The black scar oyster, Crassostrea iredalei is part of filter feeder organism and found extremely responsive to alterations in the environment from any natural contamination such as harmful algal blooms (HABs). The commercial demand of oyster is therefore of utmost importance to monitor the presence and effect on related toxins at protein level. Hence, the current study involved the comparison in protein profiles of C. iredalei after exposed to toxic A. tamiyavanichi and non-toxic A. leei for 24-hour. This aimed is achievable using two-dimensional gel electrophoresis $(2-D E)$ that can identify the differential abundances of proteins spots for oyster's protein profiling. There were 12 spots detected in a pH range of 3-10 that can be predicted via cross-referring of the protein molecular weight and isoelectric points, pI in Expasy databases. These predicted proteins were involved in biological activities such as energy metabolism, cell regulation and stress response. Besides that, there were two proteins spots that have been expressed in the toxic sample and further identified using LCMS analysis. Both proteins; arginine kinase and transgelin, were highly expressed in intoxicated oyster due to the oxidative stress induced by the toxic microenvironment. The presence of A. tamiyavanichi caused toxin accumulation in oysters and might induce the disorder of energy metabolism. The regulation mechanism thus explains on the oyster stability during HAB outbreak.
\end{abstract}

Keywords: Crassostrea iredalei, Alexandrium tamiyavanichii, A. leei, harmful algal blooms, protein profiling, paralytic shellfish poisoning toxin

\section{Introduction}

Oyster has advanced commercial value in Malaysia and has been collected in a large amount for human consumption. Oyster from the species of Crassostrea iredalei has higher demand for its white colored flesh and sweet flavor. Due to the intertidal and shallow coastal water in Peninsular Malaysia, this type of filter-feeder organism is able to survive well (Lam, 2009). However, this species is prone to contamination due to accumulation of harmful toxins produced by microalgae especially the dinoflagellates. Thus, the tainted oysters rendered as unfit to human consumption.

In a normal food chain, microalgae are important to marine ecosystems as critical foods for the filter-feeding bivalve like oysters, scallops, mussels, and clams (Huang et al., 2015). These bivalves are the potential vectors for paralytic shellfish poisoning (PSP) toxin. In this case, the contaminated oysters are being associated with the occurrence of harmful algal blooms (HABs). One of the groups of microalgae known as dinoflagellate has been described as causative agent of HABs due to the toxicity attribute. The excessive growing of the toxic dinoflagellates such as Alexandrium spp. may produce phycotoxins that lead to a variety of gastrointestinal and neurological illnesses to human when consuming contaminated seafood products (Shelar et al., 2014).

The outbreak of PSP toxin producing by dinoflagellates due to HABs have been reported vigorously nowadays. Last year, a test has been conducted by the Fisheries Department prior to the outbreak in Kuantan Port (NST, 2014). During the event, a few people have been hospitalized after consumption of contaminated oyster collected in that area. Apart from Kuantan, a few cases also had been reported in Kelantan, Johor and Kota Kinabalu, Sabah (Lim et al., 2012). Although species belonging to the genus Alexandrium are known to 
produce paralytic shellfish toxins, this characteristic was not shown in A. leei (Orr et al., 2011). Hence, the protein expressed in the contaminated oyster by different Alexandrium spp. might be differed.

It is of utmost significance to monitor the safety and quality of seafood product as these shellfish are highly in demand yet easily contaminated with PSP toxins. Novel approach such as two-dimensional proteomics could become powerful tool to study the possible proteins synthesized in the contaminated oyster. Hence, this present study reviews the protein analysis of $C$. iredalei using 2-dimensional electrophoresis which will interpret the response of oyster at protein level based on different types Alexandrium sp. exposure.

\section{Materials and Method}

\subsection{Sample Acclimatization and Exposure}

The oysters (10 $\mathrm{cm} \pm 1 \mathrm{~cm}$ in length) were collected from FRI Tanjung Demong, Besut, Terengganu and then placed in aerated tanks $(10 \mathrm{~L})$ with filtered natural seawater $\left(26^{\circ} \mathrm{C}\right.$ and $\left.30 \mathrm{ppt}\right)$ for over a week. During this period, they were fed with cultured microalgae Isochyris galbana. After acclimatization to the laboratory condition, 30 oysters were randomly selected and were distributed into three similar aerated tanks (30 ppt and $\left.26^{\circ} \mathrm{C}\right)$ with ten oysters respectively. They were fed with algal cultures of I. galbana $\left(2.12 \times 10^{5}\right)$ as control, toxic A. tamiyavanichi $\left(2.06 \times 10^{5}\right)$ and non-toxic A. leei $\left(2.23 \times 10^{5}\right)$ in respective tanks. After 24-hour exposure, the oyster tissues from each tank were collected and immediately treated with liquid nitrogen and stored at $-80{ }^{\circ} \mathrm{C}$ for protein extraction.

\subsection{Protein Extraction}

Tissue powder of $1 \mathrm{~g}$ fresh weight was homogenized in $2 \mathrm{ml}$ of $7 \mathrm{M}$ urea, $2 \mathrm{M}$ thiourea, $2 \%(\mathrm{w} / \mathrm{v}) 3-[(3-$ cholamidopropyl) dimethylammonio]-1-propane sulfonate (CHAPS), $50 \mathrm{mM}$ dithiothreitol (DTT) and ampholytes (pH 4-7) (Bio-Rad, Hercules, CA, USA). Supernatant were collected upon centrifugation at 15000 $\mathrm{x} g$ for 30 minutes. $10 \% \mathrm{TCA} /$ acetone buffer was added later to the supernatant and allowed to precipitate at $4{ }^{\circ} \mathrm{C}$ for 30 minutes (Campos et al., 2012; Wang et al., 2009). The centrifugation step was at $15000 \mathrm{x}$ g for 30 minutes, $4{ }^{\circ} \mathrm{C}$. The pellet obtained from centrifugation was pooled and washed three times with ice cold acetone containing $20 \mathrm{mM}$ DTT. The pellet obtained was finally dried under vacuum in the laminar hood for several min. The dried pellets were solubilised in $500 \mu \mathrm{l}$ rehydration buffer and stored at $-80{ }^{\circ} \mathrm{C}$ until further analysis. Proteins were quantified using Bradford method (Bradford, 1976).

\subsection{One-dimensional Protein Electrophoresis}

The amount of protein loaded into each well was $50 \mu \mathrm{g}$ for each sample. Gel electrophoresis was carried out at $200 \mathrm{~V}$ for approximately $45 \mathrm{~min}$ until the bromophenol blue dye migrates out of the gel entirely. The gels were stained using Coomassie Blue R250 followed by destaining procedures.

\subsection{Two-dimensional Protein Separation (IEF and SDS-PAGE)}

Each protein sample (200 $\mu \mathrm{g}$ of protein) was diluted to $125 \mu \mathrm{L}$ in rehydration buffer ( $7 \mathrm{M}$ urea, $2 \mathrm{M}$ thiourea, $40 \mathrm{mM}$ Tris-base (pH 8.8), $2 \%$ (w/v) CHAPS in distilled water) and loaded onto $7 \mathrm{~cm}$ in length with pH 3 to 10 of non-linear IPG strip (Bio-Rad) and the rehydration steps took place for 12-hour. The proteins then being separated by isoelectric focusing (IEF) in a Protean ${ }^{\circledR}$ i12TM IEF Cell (Bio-Rad) with the following programme: step 1, 33 min at $250 \mathrm{~V}$; step 2, 2-h voltage gradient to $4000 \mathrm{~V}$ (linear ramp); step 3, $4000 \mathrm{~V}$ until achieving 10 000 Vh-1. After IEF, the strips were equilibrated in buffer containing $375 \mathrm{mM}$ Tris-base (pH 8.8), $6 \mathrm{M}$ urea, $25 \%$ (v/v) glycerol, $2 \%(\mathrm{w} / \mathrm{v})$ SDS, $2.5 \%(\mathrm{w} / \mathrm{v})$ acrylamide and $125 \mathrm{mM}$ DTT. Second dimension was carried out following the method for SDS-PAGE. Gel images were viewed and analyzed using PDQuest.

\subsection{Protein Identification (LCMS)}

Two spots of interest were excised and sent for LCMS analysis by First Base Company. The protein samples were trypsin digested and peptides extracted according to standard techniques (Bringans et al. Proteomics 2008). Peptides were analysed by electrospray ionisation mass spectrometry using the Shimadzu Prominence nano HPLC system [Shimadzu] coupled to a 5600 Triple TOF mass spectrometer [Sciex]. Tryptic 
peptides were loaded onto an Agilent Zorbax 300SB-C18, $3.5 \mu \mathrm{m}$ [Agilent Technologies] and separated with a linear gradient of water/acetonitrile/ $0.1 \%$ formic acid (v/v). Spectra were analysed to identify proteins of interest using Mascot sequence matching software [Matrix Science] with MSPnr100 database.

\section{Result and Discussion}

The amount of protein quantified from Bradford analysis is shown in Table 1.

TABLE I: Protein concentration of $C$. iredale $i$ at different exposure treatment and time.

\begin{tabular}{cc}
\hline \hline Sample Exposure & Concentration, $\mathrm{x}(\mu \mathrm{g} / \mathrm{ml})$ \\
\hline A. leei & 0.3704 \\
A. tamiyavanichi & 0.3800 \\
\hline \hline
\end{tabular}

Fig. 1 displays the images obtained from one dimensional analysis of proteins extracted using the modification methods from three different exposure treatments. From the figure, it is showed that all the samples exhibit similar band size and resolved higher intensity approximately at $35 \mathrm{kDa}$. Apart from that, the other band size can be clearly seen at the size range bigger than $40 \mathrm{kDa}$. However, in term of degree of expression, there is no obvious different of band sizes and intensities in comparison for both toxic A. tamiyavanichi and non-toxic $A$. leei.

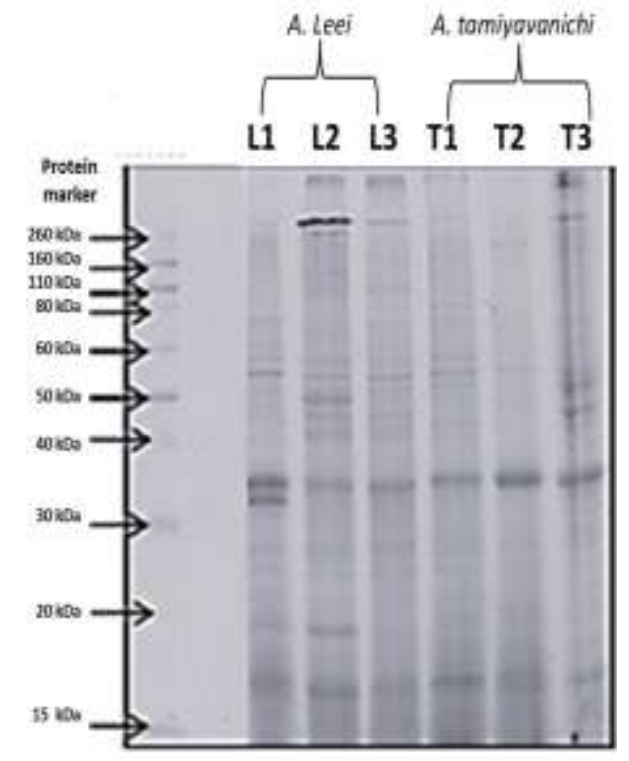

Fig. 1: One dimensional gel electrophoresis images of $C$. iredalei upon exposure with toxic A. tamiyavanichi and non-toxic A.leei. (C: control; L: A. leei; T: A. tamiyavanichi; and 1-3: replicates)

The higher band intensity can be clearly seen for all of the exposure treatment at the size of $35 \mathrm{kDa}$. However, there were many bands observed in the range of 30 until $50 \mathrm{kDa}$ even though at lower intensity. According to the study that has been conducted by Campos et al., (2012), majority of the structural proteins were available in that range of size. The examples of proteins involved are actin, tubulin, myosin, centrin and tektin that contribute in cytoskeleton structure and dynamics.

\subsection{TWO-DE and Pdquest Analysis}

Proteomic profiles of $C$. iredalei that has been exposed with non-toxic A. leei and toxic A. tamiyavanichi after 24 hours were compared and showed in Fig. 2 and Fig 3 respectively. 


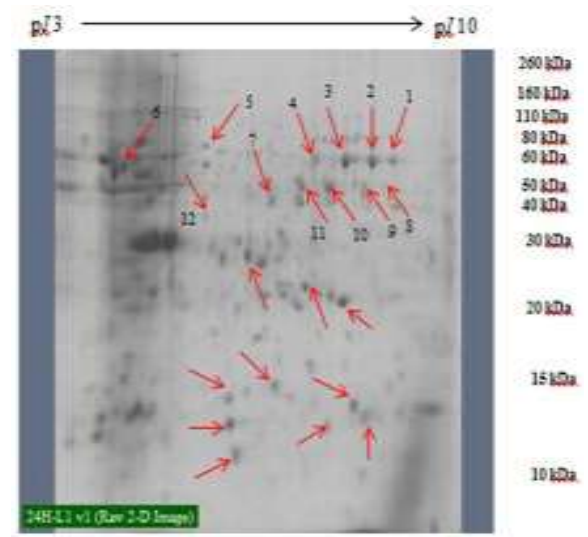

Fig. 2: The red arrow shows the matched spot detected with the exposure of non-toxic A. leei with higher intensity.

Approximately there were about 617 spots reproducibly detected in the non-toxic A. leei exposure sample and 696 spots were observed from the exposure sample by toxic A. tamiyavanichii. Most of the spots appeared at the molecular weight of $10-80 \mathrm{kDa}$. Some of the most abundance and matched spots that was detected in both toxic and non-toxic sample is shown in the Fig. 3.

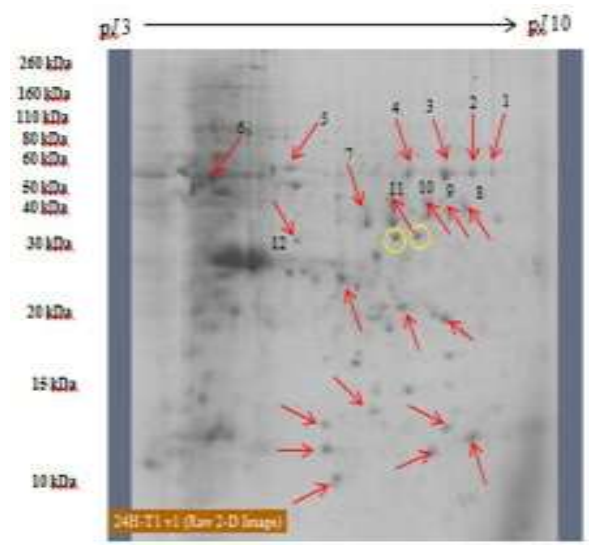

Fig. 3: The red arrow shows the matched spot detected with the exposure of toxic A. tamiyavanichi that gave higher intensity. The yellow circles indicate the unmatched spot (left: SSP 6402 and right: SSP 6403) that presence only in the toxic sample which obtained from PDQuest analysis.

Oyster is a primary benthonic organism in coastal water, which can accumulate PSP toxins from harmful algae by filtering the large amount of seawater. There were studies conducted on behavioral and physiological response of oysters upon exposure to toxic dinoflagellates which allows them to become resistant. However, the understanding on oyster's mechanism of regulating the toxic condition is still lacking but has been characterized in other crustaceans. The main idea of this study is to compare the expression of oyster proteins from two different exposure treatments which are toxic, A. tamiyavanichii and non-toxic, A. leei. The additional of TCA extraction protocol is necessary in removal of contaminants to increase 2-DE resolution and important for digestion prior to mass spectrophotometry (Kim, 2006).

Based on the SDS-PAGE images, the presence of protein bands obtained from all samples was found similar in size regardless of the exposure treatment. Smearing was observed as a consequence from running of membrane associated proteins with high lipid content (Gomez-Mendikute et al., 2005). The higher band intensity can be clearly seen for all of the exposure treatment at the size of $35 \mathrm{kDa}$ if compared to the other band size. However, there were many bands observed in the range of 30 until $50 \mathrm{kDa}$ even though at lower intensity. According to the study that has been conducted by Campos et al. (2012), majority of the structural proteins were available in that range of size such as actin, tubulin, myosin, centrin and tektin that contribute in cytoskeleton structure and dynamics.

From the sequencing analysis of the first spot (SSP 6402), arginine kinase (AK) was identified with close relatedness to the $\mathrm{AK}$ in $C$. gigas. Arginine kinase is known as one type of allergens presence in most bivalves 
(Takeuchi et al., 2003). It basically stimulates energy homeostasis by catalyzing a reversible phosphorylation reaction to either produce or conserve ATP under energy fluctuation (Chen et al., 2014; Takeuchi et al., 2003). In present study, the presence of toxic microalgae as the feed for the oyster stimulates high expression of AK. The up regulation of $\mathrm{AK}$ was observed in $C$. iridale $i$ fed with toxic A. tamiyavanichii when compared to the profile of $C$. iridalei contaminated with non-toxic A. leei. The toxin released from A. tamiyavanichii may induce oxidative stress condition which in returns enhanced ATP synthesis in oyster via elevated AK activity. Previous studies showed that the difference of AK activity is highly controlled by external factors such as abiotic stress and water contaminants. This result coincides with the high expression of $\mathrm{AK}$ detected during interaction between toxic cyanobacteria and zooplankton by Lyu et al. (2015). They also explained the possibility of zooplankton to be resistant towards toxic cyanobacteria due to its ability to regenerate ATP under stress condition. It thus supports the idea of oyster stability during HAB events. Most shellfish able to survive during toxic microalgae attack as they can quickly recover the after effects via unresolved mechanisms and increased AK activity is one of the possible routes.

Expression of transgelin (SSP 6403) was expected in this study as it is crucial as actin-binding protein in smooth muscle of organism as a whole. Oysters are benthic invertebrates that move their mussel for phagocytic purpose. Apart from regulating muscle contraction, transgelin is a potential biomarker in tumor development among cancer patients where in most cases its biological functions are tumor-specific (Zhou, 2012). The study detected transgelin upregulation in pancreatic cell of diabetic patient. The research was based on findings by Zhang et al. (2009) whom discovered that hypoxia of microenvironment within smooth muscle responsible for overexpression of transgelin in hypertension patient. The significant of this protein was least studied in invertebrates in which movement are finite. It was identified in prawn (Jung et al., 2011), recorded high in oyster larvae (Dineshram et al., 2013) and presence in significant amount within abalone (Wang et al., 2008). In present study, the upregulation of transgelin in intoxicated oyster was probably induced by the oxidative stress as mentioned earlier. Toxic environment favors the synthesis of transgelin in order to revert the normal activity of smooth muscle in the oyster.

Proteomic approach described in this study is an important tool to investigate the expression of $C$. iredalei towards exposure to both toxic and non-toxic Alexandrium species. The exposure of $C$. iredalei to toxic $A$. tamiyavanichi has caused PSP toxin accumulation whereby the protein is differently expressed. In total, there were about 617 spots reproducibly detected in the non-toxic A. leei exposure sample and 696 spots were observed from the exposure sample by toxic A. tamiyavanichi. However, only 12 proteins were managed to be matched with the protein entries in the database. The two identified proteins were highly expressed probably due to the oxidative stress induced by the toxic microenvironment within the oyster. However, further analysis on the gene expression of the proteins is highly recommended to explain in details the upregulation of these proteins in oysters fed with A. tamiyavanichii.

\section{Acknowledgements}

This project was funded by Fundamental Research Grant Scheme (FRGS14-146-0387) from Malaysian Ministry of Higher Education.

\section{References}

[1] Bradford, M. M. (1976). A rapid and sensitive method for the quantitation of microgram quantities of protein utilizing the principle of protein-dye binding. Analytical Biochemistry, 72(1), 248-254.

https://doi.org/10.1016/0003-2697(76)90527-3

[2] Campos, A., Puerto, M., Prieto, A., Cameán, A., Almeida, A. M., Coelho, A. V., \& Vasconcelos, V. (2013). Protein extraction and two-dimensional gel electrophoresis of proteins in the marine mussel Mytilus galloprovincialis: An important tool for protein expression studies, food quality and safety assessment. Journal of the Science of Food and Agriculture, 93: 1779-1787. https://doi.org/10.1002/jsfa.5977

[3] Faurobert, M., Pelpoir, E., \& Chaib, J. (2007). Phenol extraction of proteins for proteomic studies of recalcitrant plant tissues. Meth Mol Biol, 355:9-14. 
[4] G'omez-Mendikute A., Elizondo, M., Venier, P., \& Cajaraville M. P. (2005). Characterization of mussel gill cells in vivo and in vitro. Cell Tissue Res 321: 131-140.

https://doi.org/10.1007/s00441-005-1093-9

[5] Hames, B. D. (Ed.). (1998). Gel Electrophoresis of Proteins: A Practical Approach. 197. Oxford University Press.

[6] Huang, L., Zou, Y., Weng, H., Li, H., \& Liu, J. (2015). Proteomic profile in Perna viridis after exposed to Prorocentrum lima, a dinoflagellate producing DSP toxins. Environmental Pollution, 196, 350-357. https://doi.org/10.1016/j.envpol.2014.10.019

[7] Kim, S. C. (2006). A clean, more efficient method for in-solution digestion of protein mixtures without detergent or urea. J. Proteome Res. 5: 3446-3452. https://doi.org/10.1021/pr0603396

[8] Laemmli, U. K. (1970). Cleavage of structural proteins during the assembly of the head of bacteriophage T4. Nature, 227(5259), 680-685. https://doi.org/10.1038/227680a0

[9] Lam, K. (2009). Oysters (bivalvia : ostreidae and gryphaeidae) recorded from Malaysia and Singapore, 57(2): 481-494.

[10] Lim, H. C., Leaw, C. P., Tan, T. H., Kon, N. F., Yek, L. H., Hii, K. S. (2012). A bloom of Karlodinium australe (Gymnodiniales, Dinophyceae) associated with mass mortality of cage-cultured fishes in West Johor. Harmful Algae, 40:51-62. https://doi.org/10.1016/j.hal.2014.10.005

[11] Navarro, J. M., Contreras, A. M., \& Chaparro, Ó. R. (2008). Short-term feeding response of the mussel Mytilus chilensis exposed to diets containing the toxic dinoflagellate Alexandrium catenella. Revista Chilena de Historia Natural, 81:41-49. https://doi.org/10.4067/S0716-078X2008000100004

[12] Orr, R. J. S., Stuken, A., Rundberget, T., Eikrem, W., \& Jakobsen, K. J. (2011). Improved phylogenetic resolution of toxic and non-toxic Alexandrium strains using a concatenated rDNA approach. Harmful Algae, 10. https://doi.org/10.1016/j.hal.2011.05.003

[13] Shelar, P. S., Gauri, S., Desai, S., Kavitha, M., \& Padmavathy, P. (2014). Marine biotoxins and its detection. African Journal of Environmental Science and Technology, 8(6): 350-365. https://doi.org/10.5897/AJEST12.065

[14] Tomanek, L. \& Zuzow, M., J. (2010). The proteomic response of the mussel congeners Mytilus galloprovincialis and $M$. trossulus to acute heat stress: implications for thermal tolerance limits and metabolic costs of thermal stress. $J$ Exp Biol, 213:3559-3574 https://doi.org/10.1242/jeb.041228.

[15] Xu, Y. Y., Liang, J. J., Yang, W. D., Wang, J., Li, H. Y., \& Liu, J., S. (2014). Cloning and expression analysis of Pglycoprotein gene in Crassostrea ariakensis. Aquaculture, 418: 39-47.

https://doi.org/10.1016/j.aquaculture.2013.10.004 